\title{
ASZÁLYINDEXEK ÖSSZEHASONLÍTÓ ELEMZÉSE A PANNON-RÉGIÓ ALFÖLDI TERÜLETEIRE
}

\author{
Kis Anna ${ }^{(1,2)}$ (D), Pongrácz Rita ${ }^{(1,2)}$ (D), Bartholy Judit ${ }^{(1,2)}$ (D), \\ Milan Gocic $^{(3)}$ D, Slavisa Trajkovic ${ }^{(3)}$ (D), Mladen Milanovic ${ }^{(3)}$ \\ ${ }^{(1)}$ ELTE Meteorológiai Tanszék, 1117 Budapest, Pázmány Péter sétány 1/A \\ ${ }^{(2)}$ ELTE TTK Kiválósági Központ, 2462 Martonvásár, Brunszvik u. 2. \\ ${ }^{(3)}$ University of Nis, Faculty of Civil Engineering and Architecture, Nis, Serbia \\ e-mail:kisanna@nimbus.elte.hu,prita@nimbus.elte.hu,bartholy@caesar.elte.hu, \\ milan.gocic@gaf.ni.ac.rs, slavisa.trajkovic@gaf.ni.ac.rs,mladen.milanovic@gaf.ni.ac.rs
}

\section{Bevezetés}

Számos koordinált kutatás kapcsolódik a globális éghajlati rendszer müködésének pontosabb megértését célzó, átfogó nemzetközi programhoz, a WCRP ${ }^{1}$-hez. Ezek egyike a PannEx (Ceglar et al., 2018): a WCRP részeként müködő GEWEX² keretében létrejött nemzetközi kezdeményezés, amelynek célja, hogy jobban megértsük a Pannon-medence térségének regionális éghajlati viszonyait alakító folyamatokat, valamint a felszín és a légkör között lejátszódó kölcsönhatásokat. A PannEx iránt érdeklődő, elsősorban régióbeli kutatóintézetekben, egyetemeken dolgozó résztvevők sokféle kutatási szakterületet fednek le, amelyeket öt vezértéma köré csoportosíthatunk: mezőgazdaság, levegőminőség, fenntartható fejlődés, vízgazdálkodás és oktatás. Az ezekkel a tárgykörökkel kapcsolatos legfontosabb megválaszolandó tudományos kérdéseket egy hosszabb összegző tanulmány (Lakatos et al., 2018) foglalja össze.

A PannEx kezdeményezés tehát a Magyarországot teljes mértékben lefedő Kárpátmedence térségére fókuszál, és támogatja a nemzetközi együttmüködéseket annak érdekében, hogy integrált megközelítéssel vizsgálhassuk a klímaváltozás, illetve az antropogén tevékenység környezeti hatásait, továbbá megfelelő tudományos alapot biztosítson az adaptációs stratégiák kidolgozásához. Jelen kutatásunk - amely a Pannon régió aszályainak és heves esőzéseinek elemzésére irányul (az elmúlt néhány évtizedet és a XXI. századot tekintve) - egy hivatalosan 2017. ősz végén kezdődött, két évre szóló szerb-magyar bilaterális kapcsolat keretében indult.

\section{Adatok, módszerek}

Kutatásunkban Magyarország és Szerbia alföldi területeire fókuszáltunk (1. ábra), hiszen a mezőgazdasági termelés miatt ezen régiók aszályhajlamának vizsgálata mind a múltra, mind a jövöre vonatkozóan különösen fontos. A múltra vonatkozó elemzésekhez az állomási mérések alapján összeállított CARPATCLIM (Spinoni et al., 2015) adatbázist használtuk, amely napi léptékben áll rendelkezésre az 1961-2010 időszakra. A jövőre becsült tendenciák meghatározásához a RegCM4.3 regionális klímamodell (Elguindi et al., 2011) tanszékünkön végzett szimulációit alkalmaztuk (Pieczka et al., 2018) az RCP8.5 forgatókönyv (van Vuuren et al., 2011) figyelembe vételével.

Validációs vizsgálatok során bebizonyosodott, hogy a RegCM4.3 múltra vonatkozó szimulációs eredményei szisztematikus hibával terheltek (Kis et al., 2017a) - ennek kiküszöbö-

\footnotetext{
${ }^{1}$ WCRP: World Climate Research Programme (Klímakutatási Világprogram)

${ }^{2}$ GEWEX: Global Energy and water EXchanges (Globális energia- és vízcsere)
} 
lésére percentilis-alapú hibakorrekciót (Kis et al., 2017b) hajtottunk végre a nyers modelloutputokon azért, hogy számításainkat mind a múltra, mind a jövőre vonatkozóan megbízhatóbb idősorokkal végezhessük.

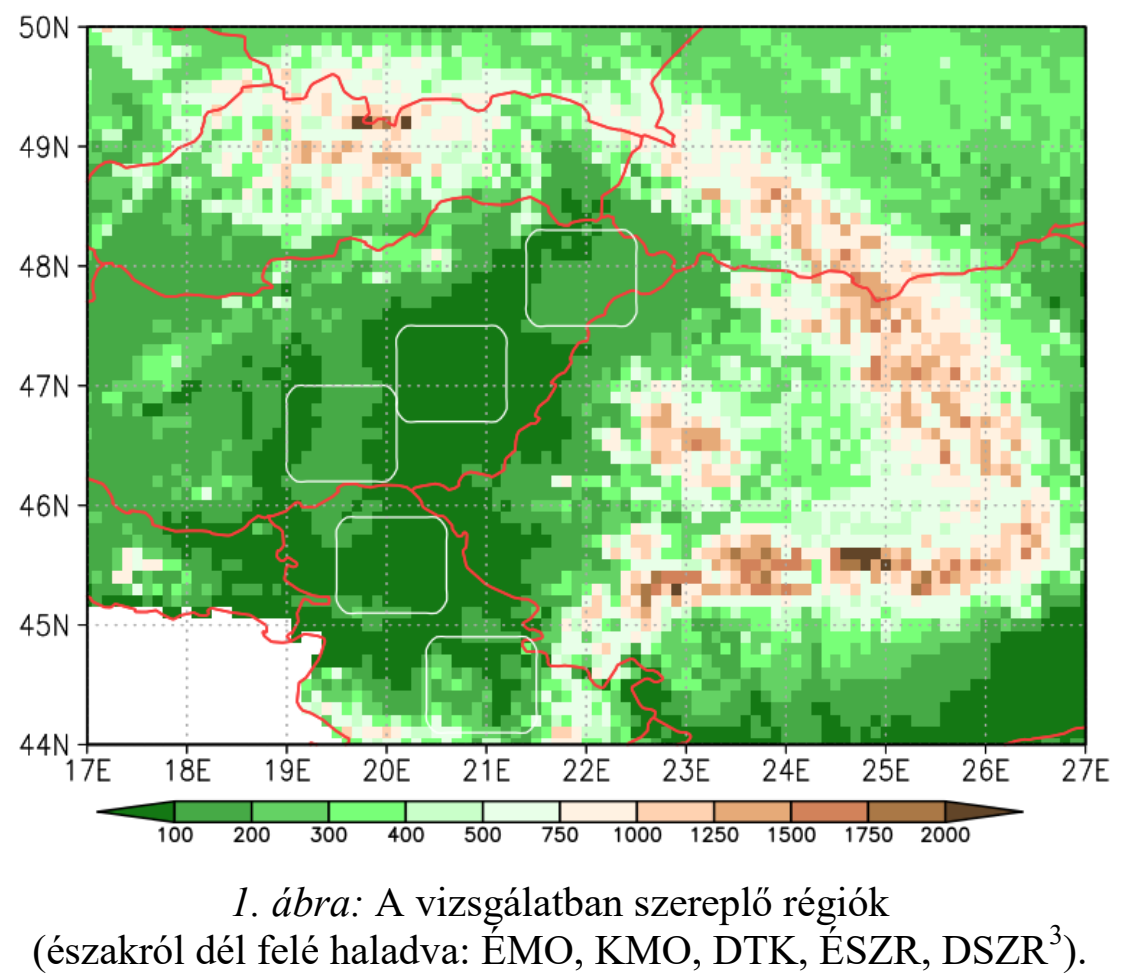

Az aszály jellemzésére számtalan indexet definiáltak, melyek osztályozása, felhasználásuk előnyeinek és hátrányainak részletes leírása megtalálhatók a szakirodalomban (pl.: Dunkel, 2009; Bartholy et al., 2013). Ezek közül e tanulmányban kettőt választottunk ki, amelyekre vonatkozó eredményeinket a következő alfejezetben ismertetjük majd. Az egyik index a száraz időszakok hosszát tekinti, ez a $\mathrm{CDD}^{4}$, ami az egymást követő száraz napok (amikor a napi csapadékösszeg nem haladja meg az $1 \mathrm{~mm}-\mathrm{t}$ ) maximális számát jelöli. A CDD-t három 30 év hosszúságú periódus (1971-2000, 2021-2050, 2069-2098) havi adatai alapján határoztuk meg. E tanulmány keretében a csapadékviszonyok jellemzésére vonatkozóan még egy paramétert, az ún. RVI ${ }^{5}$ indexet mutatjuk be, amelyet Gocic \& Trajkovic (2013) Szerbia egyes állomásaira vizsgált már - itt azonban rácsponti adatbázisok alapján számolunk. Az RVI értéke az alábbi képlet segítségével határozható meg, éves bontásban:

$$
R V I=\frac{(R-R \mathbf{a} t l)}{\sigma}
$$

ahol $R$ az évi csapadékmennyiség (adott évben), Rátl az átlagos évi csapadékmennyiség és $\sigma$ ennek szórása, amelyek az 1971-2000 referencia időszak alapján kerültek kiszámításra (a jövőre vonatkozó számításoknál is ezen átlag- és szórásértékeket alkalmaztuk, az összehasonlíthatóság érdekében). Könnyen belátható, hogy ha az RVI értéke egynél kisebb, akkor száraz időszak jellemzi a térséget, míg az egynél nagyobb index-értékek nedvesebb klímára utalnak.

\footnotetext{
${ }^{3}$ ÉMO, KMO, DTK, ÉSZR, DSZR: Észak-Magyarország, Közép-Magyarország, Duna-Tisza köze, ÉszakSzerbia, Dél-Szerbia

${ }^{4}$ CDD: Consecutive Dry Days (egymást követő száraz napok)

${ }^{5}$ RVI: Rainfall Variability Index (csapadékváltozékonysági index)
} 


\section{Eredmények}

A RegCM4.3 szimuláció korrigált csapadék-outputjainak felhasználásával számított RVI értékek alapján meghatározott száraz évek előfordulási gyakoriságának térbeli szerkezetét a 2. ábrán mutatjuk be a három vizsgált időszakra vonatkozóan, évtizedes bontásban. Látható, hogy a referencia időszakban egyik rácspontban sem fordult elő 9-nél magasabb érték, illetve, hogy az 1981-1990-es évtized volt átlagosan a legszárazabb. Mindhárom múltbeli évtizedre egységesen jellemző térbeli struktúra nem figyelhető meg. A vizsgált modellszimuláció idősora alapján a XXI. századra az index növekedése becsülhető: mind a 2021-2030, mind a 2089-2098 időszakban nem ritka a 9-nél magasabb RVI. A magasabb értékek jellemzően a vizsgált terület keleti felén jelennek meg; nyugatról kelet felé haladva kirajzolódik a szárazság mértékének növekedése.
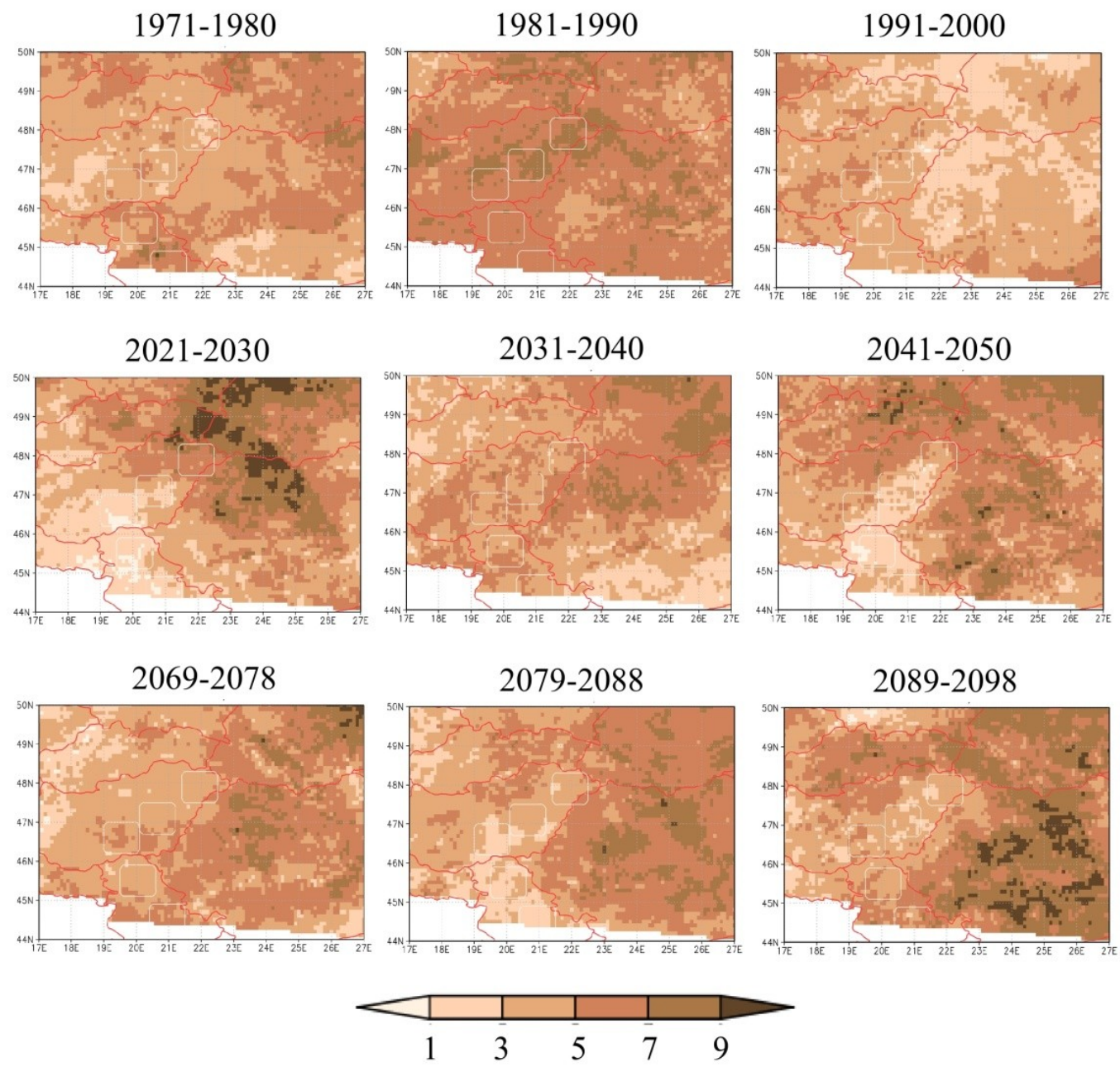

2. ábra: A száraz évek gyakorisága évtizedenként az RVI index alapján.

Az egyes régiókban a referencia időszak területi átlagát tekintve nincsenek jelentős eltérések. Általánosságban kiemelhető a középső évtized, amikor viszonylag magas volt a száraz évek száma (1. táblázat). A XXI. század közepére vonatkozó becslések is hasonlók az egyes tartományokra vonatkozóan, csupán Észak-Magyarország és Közép-Magyarország tünik ki valamelyest magasabb értékeivel a 2021-2030-as évtizedben. A távolabbi jövőre szimulált RVI esetén sem tapasztalhatók nagyobb különbségek az egyes régiók között. 
Kis A., Pongrácz R., Bartholy J., Gocic M., Trajkovic S., Milanovic M.:

Aszályindexek összehasonlító elemzése a Pannon-régió alföldi területeire

1. táblázat: A száraz évek előfordulási gyakorisága évtizedenként az RVI index alapján az egyes régiókban.

\begin{tabular}{|c|c|c|c|c|c|}
\cline { 2 - 6 } \multicolumn{1}{c|}{} & ÉMO & KMO & DTK & ÉSZR & DSZR \\
\hline $1971-1980$ & 4 & 5 & 5 & 5 & 5 \\
\hline $1981-1990$ & 7 & 8 & 7 & 7 & 6 \\
\hline $1991-2000$ & 3 & 4 & 5 & 4 & 4 \\
\hline $2021-2030$ & 7 & 7 & 2 & 2 & 2 \\
\hline $2031-2040$ & 5 & 5 & 5 & 5 & 4 \\
\hline $2041-2050$ & 4 & 4 & 5 & 2 & 3 \\
\hline $2069-2078$ & 5 & 5 & 6 & 5 & 6 \\
\hline $2079-2088$ & 4 & 5 & 3 & 3 & 3 \\
\hline $2089-2098$ & 4 & 4 & 5 & 5 & 6 \\
\hline
\end{tabular}

Az egymást követő száraz napok maximális számát havi bontásban vizsgáltuk a három időszakra vonatkozóan a RegCM4.3 korrigált csapadék-outputjai alapján (3. ábra). A múltbeli időszakban nyáron volt a legalacsonyabb (8-9 nap) az index átlagos értéke a Kárpátmedencében, a jövőben viszont szeptember mellett pont ebben az évszakban számíthatunk a legnagyobb mértékü (30\%-ot meghaladó) növekedésre, amelynek eredményeként a CDD átlagos évszakos értéke meghaladhatja akár a 12 napot is. A januártól márciusig terjedő időszakban ezzel szemben csökkenő tendenciát jeleznek szimulációink.

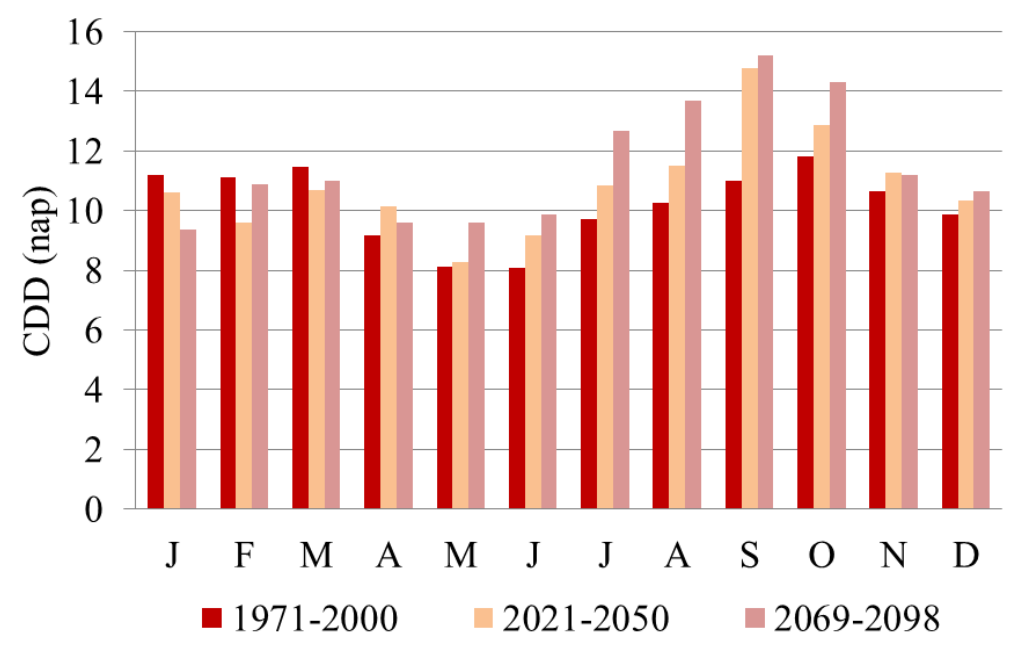

3. ábra: A CDD havi értékei a RegCM4.3 modellszimuláció alapján a három vizsgált időszakban a Kárpát-medence teljes területére vonatkozóan.

Általánosságban elmondható, hogy a távolabbi jövőhöz képest a közelebbi jövőre vonatkozóan kisebb mértékü változások valószínüsíthetők. A legjelentősebb növekedés $(43 \%)$ a XXI. század végére, Dél-Szerbiára becsülhető augusztusra (4. ábra). Ekkor 11 napról 16 napra növekszik a CDD átlagos havi értéke a vizsgált RegCM-szimuláció szerint. Érdekes, hogy a legnagyobb mértékü csökkenés is Dél-Szerbiára becsülhető: januárban $-25 \%$ a várható változás. A márciustól decemberig tartó időszakban mind az öt régióban a száraz időszakok hosszabbodására számíthatunk, amely júliusban és augusztusban lesz a legjelentősebb (20\%ot meghaladó) a RegCM-outputok alapján. Januárban és márciusban 5-20\%-os csökkenés valószínüsíthető. Februárban és áprilisban a régiók között előjelbeli különbségek jelennek meg a kismértékü várható változásra vonatkozóan: Észak-Szerbiára és a Duna-Tisza közére becsült változások iránya eltér a többitől. 
Kis A., Pongrácz R., Bartholy J., Gocic M., Trajkovic S., Milanovic M.:

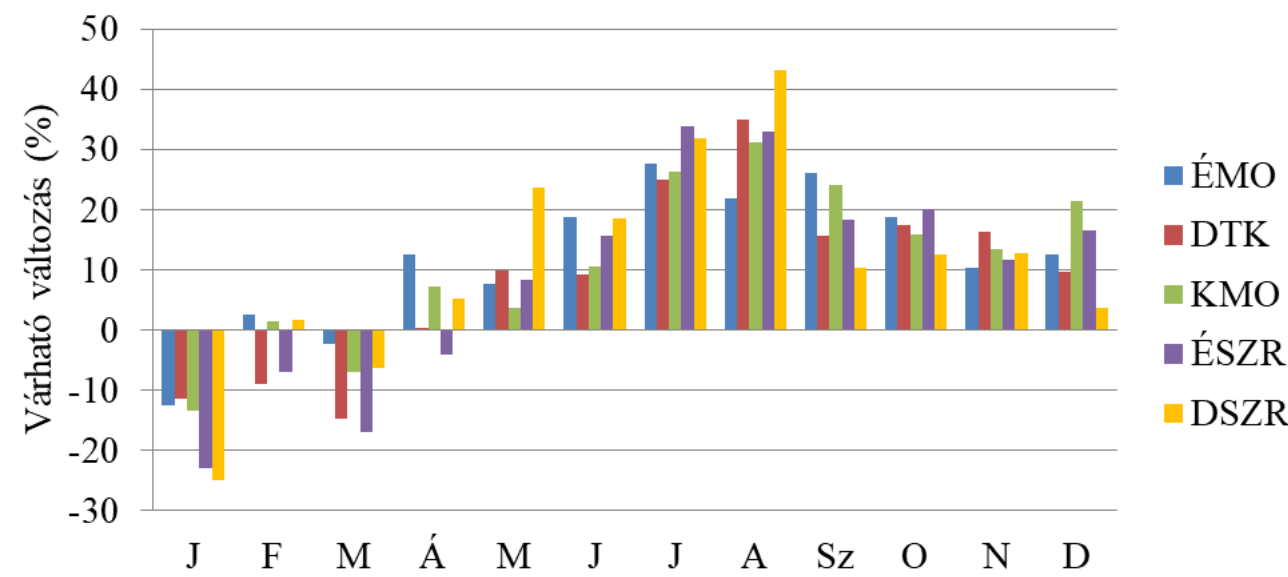

4. ábra: A CDD relatív változása (2069-2098 vs. 1971-2000) havi bontásban a RegCM4.3 modellszimuláció alapján az öt kiválasztott régióra vonatkozóan.

\section{Összefoglalás}

Jelen tanulmány keretében a szárazságot jellemző lehetséges mérőszámok közül kettőre RVI és CDD - vonatkozó eredményeinket mutattuk be Magyarország és Szerbia egyes régióira fókuszálva. A jövőre vonatkozó modellszimulációk szerint a XXI. században összességében a referencia időszakhoz (1971-2000) képest szárazabb éghajlati körülményekre számíthatunk a teljes vizsgált területen. Az RVI index esetén a becsült változásra vonatkozóan kirajzolódott egy térbeli szerkezet, miszerint a Kárpát-medence keleti felén számíthatunk hangsúlyosabb változásra. Becsléseink alapján az egymást követő száraz napok maximális száma a július és október közötti időszakban viszonylag jelentősen meg fog növekedni. További terveink között szerepel, hogy az együttmüködés keretében összetettebb indexeket is vizsgáljunk, valamint hidrológiai modellezést végezzünk a Pannon-régión belül egy-egy kiválasztott kisebb vízgyüjtő-területre.

\section{Köszönetnyilvánítás}

Kutatásainkat támogatta a szerb-magyar TÉT_16-1-2016-0135 pályázat (és ennek szerbiai kiegészítő része: a 451-03-02294/2015-09/10 pályázat), az ELTE Felsőoktatási Intézményi Kiválósági Program (1783-3/2018/FEKUTSRAT) az Emberi Erőforrások Minisztériuma támogatásával, az AGRÁRKLIMA2 projekt (VKSZ_12-1-2013-0034), a Nemzeti Kutatási, Fejlesztési és Innovációs Alap K-120605 és K-129162 számú projektje, valamint a Széchenyi 2020 program, Magyarország Kormánya és az Európai Regionális Fejlesztési Alap az AgroMo kutatási projekt (GINOP-2.3.2-15-2016-00028) keretében. A kutatási együttmüködés létrejöttét segítette a PANNEX program. Köszönet az adatokért: CARPATCLIM DatabaseCEuropean Commission - JRC, 2013.

\section{Hivatkozások}

Bartholy, J., Pongrácz, R., Hollósi, B., 2013: Analysis of projected drought hazards for Hungary. Adv. Geosci., 35: 61-66. https://doi.org/:10.5194/adgeo-35-61-2013 
Ceglar, A., Croitoru, A.E., Cuxart, J., Djurdjevic, V., Güttler, I., Ivancan-Picek, B., Jug, D., Lakatos, M., Weidinger, T., 2018: PannEx: The Pannonian Basin Experiment. Climate Services, 11: 78-85. https://doi.org/10.1016/j.cliser.2018.05.002

Dunkel, Z., 2009: Brief surveying and discussing of drought indices used in agricultural meteorology. Időjárás, 113: 23-37.

Elguindi, N., Bi, X., Giorgi, F., Nagarajan, B., Pal, J., Solmon, F., Rauscher, S., Zakey, A., Giuliani, G., 2011: Regional climatic model RegCM - User manual. Version 4.3. ICTP, Trieste, Italy. $32 \mathrm{p}$.

Gocic, M., Trajkovic, S., 2013: Analysis of precipitation and drought data in Serbia over the period 1980-2010. J Hydrol, 494: 32-42. https://doi.org/10.1016/j.jhydrol.2013.04.044

Kis, A., Pongrácz, R., Bartholy, J., Szabó, J.A., 2017a: A Felső-Tisza vízgyüjtő vizsgálata éghajlati és hidrológiai szimulációk alkalmazásával. Légkör, 62(4): 179-182.

Kis, A., Pongrácz, R., Bartholy, J., 2017b: Multi-model analysis of regional dry and wet conditions for the Carpathian Region. Int. J. Climatol., 37: 4543-4560. https://doi.org/10.1002/joc. 5104

Lakatos, M., Guettler, I., Jug, D., Weidinger, T., Djurdjevic, V., Croitoru, A., Ivancan-Picek, B., Couxart, J., eds., 2018: Regional hydro-climate project (RHP) over the Pannonian basin (PannEx). White Book. Budapest. 120p. https://sites.google.com/site/projectpannex/

Pieczka I., Pongrácz R., Bartholy J., Szabóné André K., 2018: Future temperature projections for Hungary based on RegCM4.3 simulations using new representative concentration pathways scenarios. Int. J. Global Warming, 15: 277-292. https://doi.org/10.1504/IJGW.2018.093121

Spinoni, J. and the CARPATCLIM project team (39 authors), 2015: Climate of the Carpathian Region in 1961-2010: Climatologies and Trends of Ten Variables. Int. J. Climatol., 35: 1322-1341. https://doi.org/10.1002/joc.4059

van Vuuren, D.P., Edmonds, J.A., Kainuma, M., Riahi, K., Thomson, A.M., Hibbard, K., Hurtt, G.C., Kram, T., Krey, V., Lamarque, J.-F., Masui, T., Meinshausen, M., Nakicenovic, N., Smith, S.J., Rose, S., 2011: The representative concentration pathways: an overview. Clim. Change, 109: 5-31. https://doi.org/10.1007/s10584-011-0148-z

\section{ORCID}

Kis A. (D) https://orcid.org/0000-0002-3227-1230

Pongrácz R. (D) https://orcid.org/0000-0001-7591-7989

Bartholy J. (D) https://orcid.org/0000-0002-3911-7981

Gocic M. (iD https://orcid.org/0000-0001-8398-6570

Trajkovic S. (iD https://orcid.org/0000-0001-8294-1047 